\title{
COD Removal of Edible Oil Content in Wastewater by Advanced Oxidation Process
}

\author{
Aola Hussein Flamarz Tahir ${ }^{1}$, Nagham Obeid Kareim ${ }^{1} \&$ Shatha Abduljabbar Ibrahim ${ }^{1}$ \\ ${ }^{1}$ Faculty of Engineering, Al Mustansiriayah Unviersity, Baghdad, Iraq \\ Correspondence: Aola Hussein Flamarz Tahir, Faculty of Engineering, Al Mustansiriayah Unviersity, Baghdad, \\ Iraq. E-mail: aola90@gmail.com
}

Received: March 2, 2016 Accepted: March 17, 2016 Online Published: April 30, 2016

doi:10.5539/enrr.v6n2p57 URL: http://dx.doi.org/10.5539/enrr.v6n2p57

\begin{abstract}
Different Advanced Oxidation Processes (Photo Fenton process, Fenton process and $\mathrm{H}_{2} \mathrm{O}_{2} / \mathrm{UV}$ ) were studied in order to reduce COD from oily compounds aqueous solution using batch system. To get the optimum condition, different variables were studied for each of these processes; such as $\mathrm{pH}$, time, concentration of $\mathrm{H}_{2} \mathrm{O}_{2}$, concentration of oil, concentration of $\mathrm{FeSO}_{4} \cdot 7 \mathrm{H}_{2} \mathrm{O}$ and temperature as parameters. It was found that the optimal $\mathrm{pH}$ value for the three processes was 3 and the optimal temperature was $30^{\circ} \mathrm{C}$ for Photo-Fenton and $\mathrm{UV} / \mathrm{H}_{2} \mathrm{O}_{2}$ system and $20^{\circ} \mathrm{C}$ for Fenton process. Photo-Fenton process gave a maximum COD reduction of $80.59 \%$ (COD from 2684 to $521 \mathrm{mg} / \mathrm{l}$ ), Fenton gave $53.22 \%$ (COD from 2587-1130) and the combination of $\mathrm{UV} / \mathrm{H}_{2} \mathrm{O}_{2}$ gave a COD reduction of $22.69 \%$ (COD from 2450 to 1894). The percentage of removal found was after the total reaction time $(180 \mathrm{~min}$.). The optimum chemical reagents for Photo-Fenton, Fenton and $\mathrm{UV} / \mathrm{H}_{2} \mathrm{O}_{2}$ were as the following $\mathrm{H}_{2} \mathrm{O}_{2}=800 \mathrm{mg} / \mathrm{l}, 1500$ $\mathrm{mg} / \mathrm{l}$ and $2000 \mathrm{mg} / \mathrm{l}, \mathrm{Fe}_{2} \mathrm{SO}_{4} \cdot 7 \mathrm{H}_{2} \mathrm{O}=60 \mathrm{mg} / \mathrm{l}, 100 \mathrm{mg} / \mathrm{l}$.
\end{abstract}

Keywords: advanced oxidation process, edible oil, sunflower oil, photo-fenton, fenton, hydrogen peroxide

\section{Introduction}

Edible refined oil processing industry is a major issue of environmental concern due to the increase in production and demand in developing countries in the past three decades. The waste streams effluents creates serious environmental problem such as great threat to aquatic life due to its high organic content. Hence its treatment is essential prior to its disposal. The choice of effluent treatment methods depends on the organic content present in the effluent and its discharge conditions (Sharma et al., 2014). The oil seeds are usually processed to obtain the oil contents which are subsequently processed for human consumption and industrial applications. Thus the vegetable oil industries are, equally, associated with oil extraction, refining, transportation, uses and reuses. However, these industries have been linked with environmental pollutions resulting from oil spill, oily effluent discharge into water bodies and oily sludge discharge into the environment indiscriminately, untreated or in conditions below the standard discharge limits (Alade et al., 2011).

Crude vegetable oils are mainly triacylglycerols (around 95\%) along with some free acids, monoacylglycerols, and diacylglycerols. They also contain variable amounts of other components such as phospholipids, free and esterified sterols, triterpene alcohols, tocopherols and tocotrienols, carotenes, chlorophylls and other coloring matters, and hydrocarbons as well as traces of metals, oxidation products and some undesirable flavors (Gunstone, 2005). Vegetable oil wastewater (VOWW) has been treated in different ways. Its characteristics depend largely on the type of oil processed and on the process implemented that are high in COD, oil and grease, sulphate and phosphate content, resulting in both high inorganic as well as organic loading of the relevant wastewater treatment works. The wastewater varies both in quantity and characteristics from one oil industry to another. The composition of wastewater from the same industry also varies widely from day to day (Chin \& Wong, 1981). Also the oil type processed may be a reason for these fluctuations.

Wastewaters containing oil can be treated either in chemical or biological units. The efficiency of treatment depends on the ratio of free oil to emulsified oil. The free oil can be easily removed from wastewater by physical processes but in order to remove emulsified oil from wastewater, de-emulsification should be done. The conventional treatment of vegetable oil industry wastewater consists of mechanical dewatering of sludge produced with physical, chemical and biological processes. In general, biological treatments that are applied in the industry to treat the VOWW. It will start with oil removal and dissolved air flotation (DAF) with alum as 
coagulant before entering into biological treatments.Variation in wastewater flow and composition has led to the inefficiency of bioprocess resulting the treated effluent could not meet the discharge limits ( $\mathrm{Ng}, 2006)$.

Advanced oxidation processes (AOPs) belong to the chemical treatment category and are used to oxidise organic compounds found in wastewater which are difficult to handle biologically into simpler end products. Advanced oxidation processes (AOPS) are technologies based on the generation of hydroxyl radicals, especially the hydroxyl radical $(\mathrm{OH})$, which is highly reactive substance used to degrade toxic organic compound in a medium. The main reason why AOPs was chosen in this study is due to its reputation in treating highly recalcitrant pollutant and removal wide range of (Wols \& Hofman-Cal, 2012).

Depending upon the nature of the organic species, four types of initial attach are possible: Radical addition Equation (2.1), hydrogen abstraction Equation (2.2), electron transfer Equation (2.3) and radical combination Equation (2.4). In the following equations, $\mathrm{R}$ is used to describe the reacting organic compound (Heponiemi \& Lassi, 2012):

Radical addition: Reaction of the hydroxyl radical and unsaturated or aliphatic organic compound produces organic radical which can further oxidize by oxygen or ferrous iron to form stable oxidized end products.

$$
\mathrm{R}+\mathrm{HO} \cdot \rightarrow \mathrm{ROH}
$$

Hydrogen abstraction: Generated hydroxyl radical can be used to remove hydrogen from an organic compound forming an organic radical and initiating a chain reaction where the organic radical reacts with oxygen. This produces a peroxyl radical, which can react with another organic compound, and so on.

$$
\mathrm{R}+\mathrm{HO} \cdot \rightarrow \mathrm{R} \cdot+\mathrm{H}_{2} \mathrm{O}
$$

Electron transfer: Electron transfer results in the formation of ions with a higher valence. Oxidation of a monoatomic negative ion will result in the formation of an atom or a free radical.

$$
\mathrm{R}^{n}+\mathrm{HO} \rightarrow \mathrm{R}^{n-1}+\mathrm{HO}^{-}
$$

A radical combination: Two radicals form a stable product.

$$
\mathrm{HO} \cdot+\mathrm{HO} \cdot \rightarrow \mathrm{H}_{2} \mathrm{O}_{2}
$$

Generally, the reaction of hydroxyl radicals and organic compounds will produce water, carbon dioxide and salts (SES, 1994).

Three processes are investigated in this study:

Fenton process $\left(\mathrm{H}_{2} \mathrm{O}_{2} / \mathrm{UV}\right)$ : The conventional 'dark' Fenton process was reported first by Fenton (1894) over a century ago for the oxidation of maleic acid. The process involves the reaction between dissolved $\mathrm{Fe}^{2+}$ and hydrogen peroxide in acidic aqueous solution, leading to the formation of hydroxyl radicals.

Photo-Fenton process $\left(\mathrm{H}_{2} \mathrm{O}_{2} / \mathrm{Fe}^{+2} / \mathrm{UV}\right)$ : This process involves the hydroxyl radical ( $\left.\mathrm{\cdot OH}\right)$ formation in the reaction mixture through photolysis of hydrogen peroxide $\left(\mathrm{H}_{2} \mathrm{O}_{2} / \mathrm{UV}\right)$ and Fenton reaction $\left(\mathrm{H}_{2} \mathrm{O}_{2} / \mathrm{Fe}^{+2}\right)$.

Hydrogen peroxide/UV light process: This process includes $\mathrm{H}_{2} \mathrm{O}_{2}$ injection and mixing followed by a reactor that is equipped with UV light (200 to $280 \mathrm{~nm}$ ). During this process, ultraviolet radiation is used to cleave the $\mathrm{O}-\mathrm{O}$ bond in hydrogen peroxide and generate the hydroxyl radical.

\section{Method}

Commercial sunflower oil was been used as the model pollutant and to prepare an artificial sample. The commercial sunflower oil used was from Bil Bak, double refined sunflower oil and imported for Iraqi ministry of trade/ state company for foodstuff trading, for the purpose of ration card. It was analyzed at the Iraqi vegetable oil company laboratories (Table 1). Artificial sunflower oil-water emulsion was prepared as it is the critical level of oil wastewater. The emulsion was prepared by using $2.5 \mathrm{ml}$ of $100 \mathrm{ppm}$ sodium dodecyl sulphate (Biltrec, Spain) for every $100 \mathrm{ml}$ of oil in 1 liter distilled water (Ebrahim et al., 2013).

All experiments are conducted in a 2 Liter thermostatic batch glass reactor mounted at magnetic stirrer with hot plate (LMS-1003, DAIHAN LAB TECH, KOREA). UV radiation $(254 \mathrm{~nm})$ is produced from UV lamps (UVM $9311 \mathrm{G}, 6$ watt 4P-SE, SO SAFE WATER TECHNOLOGIES, UAE), which is set vertically at the top of the reactor. The lamp is totally immersed in the cylindrical reactor. UV lamp is covered in a quartz sleeve for protection and has the characteristics shown in Table (3.5). The distance between the lamp and the reactor wall is fixed to be $5 \mathrm{~cm}$ to ensure maximum light irradiation as shown in Figure (2.1). 
Table 1. Physical properties of sunflower oil sample

\begin{tabular}{ccc}
\hline Test & Result & Standard \\
\hline Relative Density & 0.920 & $0.918-0923$ \\
Refractive index $\left(40^{\circ} \mathrm{C}\right)$ & 1.468 & $1.467-1.469$ \\
Cloud point & 2 & $+6{ }^{\circ} \mathrm{C}$ \\
Peroxide value & 1.6 & Max. 2 \\
F.F.A & 0.05 & $0.18-0.20$ \\
Fe & 5 & Max. $15 \mathrm{ppm}$ \\
Colour & $0.9 \mathrm{R} 4.8 \mathrm{Y}$ & 3R 30Y \\
Odor & Acceptable & Acceptable \\
\hline
\end{tabular}

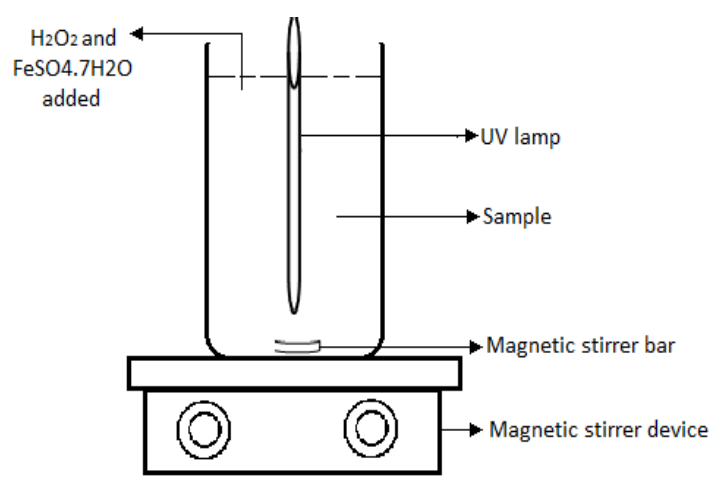

Figure 1. Laboratory unit - scale batch reactor

\subsection{Reagents}

All the reagents used in the experiments was research grade reagents without further purification whereby $\mathrm{H} 2 \mathrm{O} 2$ $\left(50 \%\right.$, w/w) from Solvochem, $\mathrm{FeSO}_{4} \cdot 7 \mathrm{H}_{2} \mathrm{O}$ from Hopkin and Williams (England) and $\mathrm{Na}_{2} \mathrm{~S}_{2} \mathrm{O}_{3}, \mathrm{NaOH}$ and $\mathrm{H}_{2} \mathrm{SO}_{4}$ from Central Drug House (India).

\subsection{Analytical Method}

Chemical oxygen demand of samples was analyzed by using Lovibond Checkitdirect COD Photometer (Germany). The COD ranges used were from $0-15000 \mathrm{mg} / \mathrm{l}$ and $0-1500 \mathrm{mg} / \mathrm{l}$.

\section{Results and Discussion}

Different important factor were studied in this study to discuss its different effects on the AOP's. The performance of single Fenton's reagent, Photo-Fenton and combination of UV radiation with hydrogen peroxide for COD removal from oily compounds aqueous solution using batch system were investigated. The following topics were also studied: wastewater characterization, $\mathrm{pH}$ value, temperature, effect of $\mathrm{H}_{2} \mathrm{O}_{2}$ concentration, effect of $\mathrm{Fe}_{2} \mathrm{SO}_{4} \cdot 7 \mathrm{H}_{2} \mathrm{O}$ concentration and irradiation time.

\subsection{The Effect of Irradiation Time}

The effect of time required for the Photo-Fenton process and $\mathrm{UV} / \mathrm{H}_{2} \mathrm{O}_{2}$ in order to get best removal efficiency was studied. For both processes fixed initial amount of $\mathrm{H}_{2} \mathrm{O}_{2}, \mathrm{Fe}_{2} \mathrm{SO}_{4} \cdot 7 \mathrm{H}_{2} \mathrm{O} \mathrm{pH}$, and temperature was set. Initial oil concentration $(1000) \mathrm{mg} / \mathrm{l}(\mathrm{COD}=2500 \pm 500)$ was used in the experiments. The results for Photo-Fenton and $\mathrm{UV} / \mathrm{H}_{2} \mathrm{O}_{2}$ process plotted in Figure (1).

The optimum time that gave best removal efficiency was found after $180 \mathrm{~min}$. for both processes. It gave a total $67.07 \%$ and $16.34 \%$ COD reduction for Photo-Fenton and $\mathrm{UV} / \mathrm{H}_{2} \mathrm{O}_{2}$ process respectively. It also found that the oil degradation rate did not increase after $180 \mathrm{~min}$. process time. The removal efficiency was decrease slightly or no change. The total degradation of organic compounds undergoes this reaction sequence (Nasr et al., 2004):

$$
\text { Organic compound } \rightarrow \text { Intermediate } A \rightarrow \text { Intermediate } \mathrm{B} \rightarrow \mathrm{CO}_{2}
$$

Some intermediates are non volatiles compounds, causing the lowness of COD reduction increase. Such intermediates (quinines, acetic acid etc.) require sufficient time to push reaction beyond $\mathrm{CO}_{2}$ (Nasr et al., 2004). 


\subsection{The Effect of $\mathrm{H}_{2} \mathrm{O}_{2}$ Concentration}

The effect of initial concentration of $\mathrm{H}_{2} \mathrm{O}_{2}$ on Photo-Fenton, Fenton and $\mathrm{UV} / \mathrm{H}_{2} \mathrm{O}_{2}$ process was tested to optimize the amount of $\mathrm{H}_{2} \mathrm{O}_{2}$ required to reduce the COD. The $\mathrm{H}_{2} \mathrm{O}_{2}$ concentration range for Photo-Fenton was $(200,400$, 600, 800 and 1000) $\mathrm{mg} / \mathrm{l}$, whereas for Fenton and $\mathrm{UV} / \mathrm{H}_{2} \mathrm{O}_{2}$ the range was $(500,1000,1500,2000$ and 2500 $\mathrm{mg} / \mathrm{l})$. Fixed initial oil concentration, $\mathrm{Fe}_{2} \mathrm{SO}_{4} \cdot 7 \mathrm{H}_{2} \mathrm{O}$ concentration, $\mathrm{pH}$ and temperature was used in all experiments. The results were plotted in Figure (2).

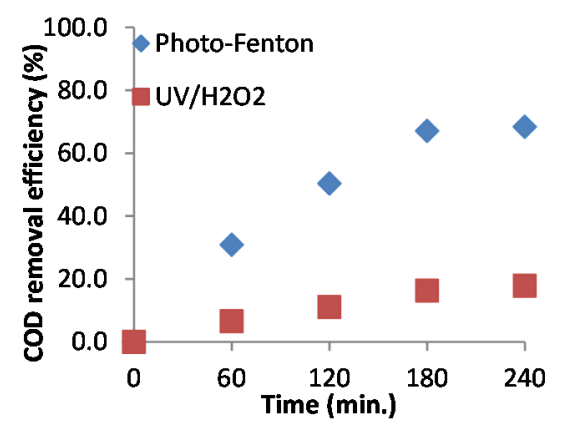

Figure 2. Effect of irradiation time on the COD removal by Photo-Fenton and $\mathrm{UV} / \mathrm{H}_{2} \mathrm{O}_{2}$ system at $\mathrm{H}_{2} \mathrm{O}_{2}=1000$ $\mathrm{mg} / \mathrm{l}, \mathrm{pH}=7$, oil conc. $=1000 \mathrm{mg} / \mathrm{l}$, temp. $=20^{\circ} \mathrm{C}$ and $\mathrm{Fe}_{2} \mathrm{SO}_{4} \cdot 7 \mathrm{H}_{2} \mathrm{O}=100 \mathrm{mg} / \mathrm{l}$ (for Photo-Fenton process only)

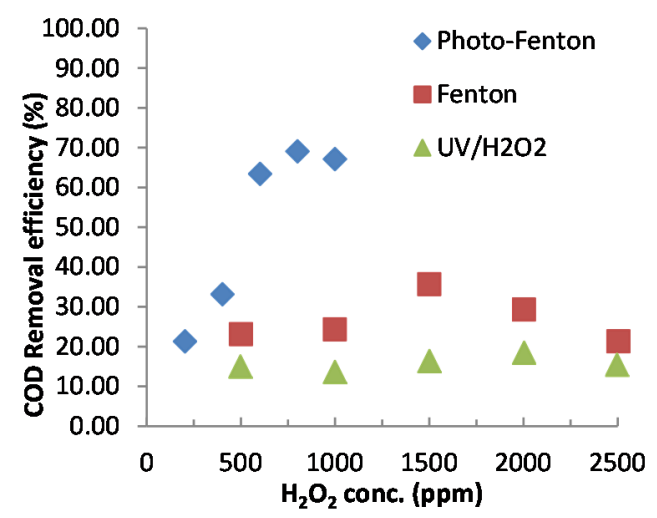

Figure 3. Effect of initial $\mathrm{H}_{2} \mathrm{O}_{2}$ concentration on the COD removal by Photo-Fenton, Fenton and $\mathrm{UV} / \mathrm{H}_{2} \mathrm{O}_{2}$ system at $\mathrm{pH}=7$, oil conc. $=1000 \mathrm{mg} / \mathrm{l}$ and temp. $=20^{\circ} \mathrm{C}$ and $\mathrm{Fe}_{2} \mathrm{SO}_{4} .7 \mathrm{H}_{2} \mathrm{O}=100 \mathrm{mg} / \mathrm{l}$ (for Photo-Fenton and Fenton process only)

From this figure it can be noticed that the COD removal increased as the concentration of $\mathrm{H}_{2} \mathrm{O}_{2}$ increased with the increasing of its dosage, reaching a maximum removal efficiency of $69.02 \%, 35.68 \%$ and $18.44 \%$ for Photo-Fenton, Fenton and $\mathrm{UV} / \mathrm{H}_{2} \mathrm{O}_{2}$, respectively. At higher $\mathrm{H}_{2} \mathrm{O}_{2}$ dosage than the optimum found there was an increase or no change in COD removal efficiency, the following point is a brief explanation about the $\mathrm{H}_{2} \mathrm{O}_{2}$ effect:

Hydrogen peroxide was the main responsible species of the degradation process by the generating of hydroxyl radicals from the direct photolysis. It can be observed that the degradation rate increased considerably when $\mathrm{H}_{2} \mathrm{O}_{2}$ was used (Esplugas et al., 2002).

After optimum $\mathrm{H}_{2} \mathrm{O}_{2}$ conc. it was found that further increase of $\mathrm{H}_{2} \mathrm{O}_{2}$ concentration retarded effluents COD. This inhibition of mineralization is probably due to both auto decomposition of $\mathrm{H}_{2} \mathrm{O}_{2}$ into oxygen and water and the scavenging of hydroxyl radicals by the excess of $\mathrm{H}_{2} \mathrm{O}_{2}$ according to the following reactions (Chatzisymeon et al., 2008):

$$
\begin{gathered}
2 \mathrm{H}_{2} \mathrm{O}_{2}+2 \mathrm{H}_{2} \mathrm{O}+\mathrm{O}_{2} \\
\cdot \mathrm{OH}+\mathrm{H}_{2} \mathrm{O}_{2} \rightarrow \mathrm{H}_{2} \mathrm{O}+\mathrm{HO}_{2}
\end{gathered}
$$

Hydroxyl radical may recombine and participate in radical-radical reactions to form $\mathrm{H}_{2} \mathrm{O}_{2}$ 


$$
\mathrm{HO} \cdot+\mathrm{HO} \cdot \rightarrow \mathrm{H}_{2} \mathrm{O}_{2}
$$

At higher $\mathrm{H}_{2} \mathrm{O}_{2}$ concentrations lower light intensity available for oil degradation, since $\mathrm{H}_{2} \mathrm{O}_{2}$ also absorb lights in the system (Ebrahim et al., 2013).

\subsection{The Effect of $\mathrm{Fe}_{2} \mathrm{SO}_{4} \cdot 7 \mathrm{H}_{2} \mathrm{O}$ Concentration}

The effects of initial $\mathrm{Fe}_{2} \mathrm{SO}_{4} .7 \mathrm{H}_{2} \mathrm{O}$ on Photo-Fenton and Fenton process were tested by carrying out experiments with different concentration of $\mathrm{Fe}_{2} \mathrm{SO}_{4} \cdot 7 \mathrm{H}_{2} \mathrm{O}(20,40,60,80$ and $100 \mathrm{mg} / \mathrm{l})$ for Photo-Fenton process and (50, 100, 150, 200 and $250 \mathrm{mg} / \mathrm{l}$ ) for Fenton process. Fixed initial oil concentration, $\mathrm{pH}$ and temperature was used in all experiments. The results were plotted in Figure (3). By these figures it can be noticed that the degradation rate of oil increased with the increasing amounts of iron salt. It reached its maximum value $(72.35 \%)$ at $60 \mathrm{mg} / \mathrm{l}$ for Photo-Fenton process and (35.68 \%) at $100 \mathrm{mg} / \mathrm{l}$ for Fenton process after about $180 \mathrm{~min}$. of irradiation time. The addition of the iron salt above these values this did not affect the degradation; it decreased and or remained unchanged.

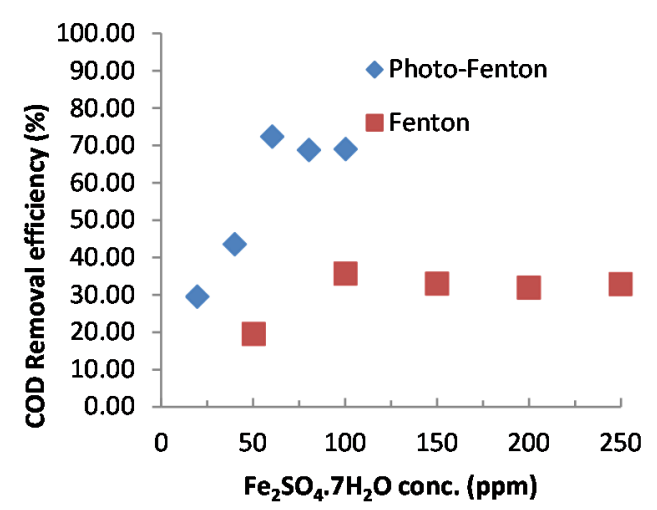

Figure 4. Effect of initial $\mathrm{Fe}_{2} \mathrm{SO}_{4} .7 \mathrm{H}_{2} \mathrm{O}$ concentration on the COD removal by Photo-Fenton, and Fenton system at $\mathrm{pH}=7$, oil conc. $=1000 \mathrm{mg} / \mathrm{l}$ and temp. $=20^{\circ} \mathrm{C}, \mathrm{H}_{2} \mathrm{O}_{2}=800 \mathrm{mg} / \mathrm{l}$ and $1500 \mathrm{mg} / \mathrm{l}$ for Photo-Fenton and Fenton process, respectively

The decrease and increase in the removal efficiency can be explained by the following points:

Addition of ferrous ions increases wastewater brown turbidity during the photo-treatment, which hinders the absorption of the UV light, required for the Photo-Fenton process (Dincer et al., 2008). Also excessive formation of $\mathrm{Fe}^{+2}$ which can compete with the organic carbon for $\mathrm{OH}$ radical may be a reason for the decrease. High $\mathrm{Fe}$ ions disposal will require another process to remove the iron residual so for an economical point of view, in this condition, it is not necessary to have high concentration of $\mathrm{Fe}$ ion (Galvão et al., 2006). Fixed $\mathrm{H}_{2} \mathrm{O}_{2}$ concentration can be the limiting factor (Rodriguez et al., 2002).

\subsection{The Effect of $p H$ Value}

The $\mathrm{pH}$ plays an important role in the AOP's and has a considerable effect on the reactions, because of the big influence to the oxidation potential of $\mathrm{OH}$ radical according to the eciprocal relation of the oxidation potential to the $\mathrm{pH}$ value $\left(\mathrm{E}_{0}=2.8 \mathrm{~V}\right.$ and $\left.\mathrm{E}_{14}=1.95 \mathrm{~V}\right)$ (Alalm \& Tawfik, 2013). Different values of $\mathrm{pH}$ were examined in this study (3,7 and 11) keeping the other parameters and dosage constant. The results are plotted in Figure (4).

Optimum $\mathrm{pH}$ was found equal to 3 for Photo-Fenton, Fenton and UV/H2O2 system which gave a removal efficiency of $(79.4 \%, 40.3 \%$ and $21.31 \%)$.

The optimum $\mathrm{pH}$ found (3) can be explained by:

The operational $\mathrm{pH}$ must be low $(\mathrm{pH}<4)$ to nullify the effect of sequestering radical species, specifically ionic species such as carbonate and bicarbonate ions, leading to a better degradation rate (Mota et al., 2008). At lower $\mathrm{pH}(<2.5)$, the formation of $\left[\mathrm{Fe}\left(\mathrm{H}_{2} \mathrm{O}\right)_{6}\right]^{2+}$ complex occurs. These reacts more slowly with $\mathrm{H}_{2} \mathrm{O}_{2}$ than does $\left[\mathrm{Fe}(\mathrm{OH})\left(\mathrm{H}_{2} \mathrm{O}\right)_{5}\right]^{+}$complex therefore produces less amount of reactive hydroxyl radicals thereby reducing the COD removal efficiency as mentioned by (De Laat and Gallard, 1999). At high $\mathrm{pH}$, iron reacts with the hydroxide ions (HO-), precipitating the iron hydroxide $\left(\mathrm{Fe}(\mathrm{OH})_{2}\right.$ or $\mathrm{Fe}(\mathrm{OH})_{3}$, which does not react with $\mathrm{H}_{2} \mathrm{O}_{2}$, which will decrease the degradation rate (Mota et al., 2008).. The removal efficiency of COD was improved at 
the acidic conditions, raising the $\mathrm{pH}$ from 3 to 7 decreased the COD removal efficiency. Similar findings was reported by ( $\mathrm{Li}$ et al., 2009) who found that the decomposition rate of $\mathrm{H}_{2} \mathrm{O}_{2}$ is low at $\mathrm{pH}$ exceeding 4 resulting a drop in the hydroxyl radicals production In high $\mathrm{pH}$ condition, the reaction between $\mathrm{Fe}^{3+}$ and $\mathrm{OH}$ - will leads to the formation of $\mathrm{Fe}(\mathrm{OH})_{3}$. This species will start to precipitate after $\mathrm{pH} 4.8$ based on the calculation from its solubility constant value; $\mathrm{K}_{\mathrm{sp}}\left(\mathrm{Fe}(\mathrm{OH})_{3}\right.$ is $2.79 \mathrm{E}^{-9}$ This precipitate will then act as coagulant. Therefore, it is expected that no dominance oxidation and $\mathrm{OH}$ radicals generation will occur at this stage (Fadzil et al., 2013).

An adjustment in $\mathrm{pH}$ may be required in the wastewater to be treated before adding the Fenton reagents.

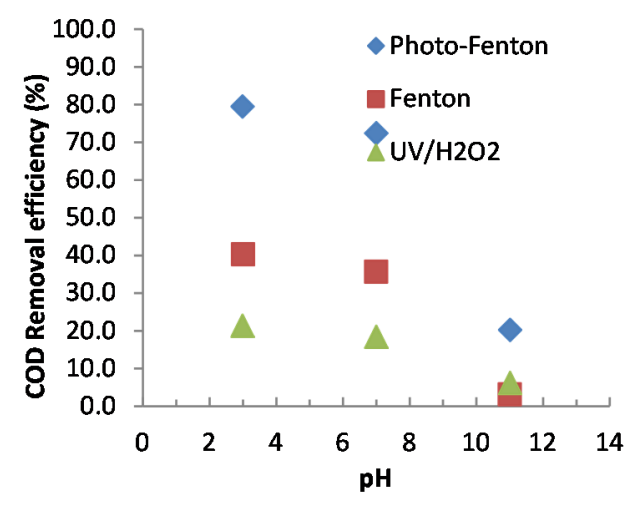

Figure 5. Effect of $\mathrm{pH}$ value initial concentration on the COD removal by Photo-Fenton, Fenton and $\mathrm{UV} / \mathrm{H}_{2} \mathrm{O}_{2}$ system at oil conc. $=1000 \mathrm{mg} / \mathrm{l}$ and temp. $=20^{\circ} \mathrm{C}, \mathrm{H}_{2} \mathrm{O}_{2}=800 \mathrm{mg} / \mathrm{l}, 1500 \mathrm{mg} / \mathrm{l}, \mathrm{H}_{2} \mathrm{O}_{2}=2000$ and $\mathrm{Fe}_{2} \mathrm{SO}_{4} .7 \mathrm{H}_{2} \mathrm{O}$ $=60 \mathrm{mg} / \mathrm{l}, 100 \mathrm{mg} / \mathrm{l}$ for Photo-Fenton, Fenton process and $\mathrm{UV} / \mathrm{H}_{2} \mathrm{O}_{2}$ system, respectively

\subsection{The Effect of Oil Concentration}

Different concentrations of vegetable oil (1000, 2000 and 3000) $\mathrm{mg} / \mathrm{l}$ were used at fixed $\mathrm{pH}$, temperature, $\mathrm{H}_{2} \mathrm{O}_{2}$ and $\mathrm{Fe}_{2} \mathrm{SO}_{4} \cdot 7 \mathrm{H}_{2} \mathrm{O}$ dosage for all experiments. The results were plotted in Figure(5).

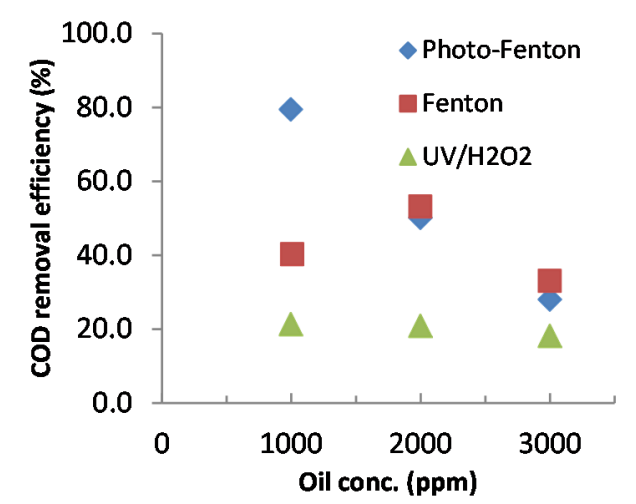

Figure 6. Effect of oil concentration on the COD removal at $\mathrm{pH}=3$, temp. $=20^{\circ} \mathrm{C}, \mathrm{H}_{2} \mathrm{O}_{2}=800 \mathrm{mg} / \mathrm{l}, 1500 \mathrm{mg} / \mathrm{l}$, 2000 and $\mathrm{Fe}_{2} \mathrm{SO}_{4} .7 \mathrm{H}_{2} \mathrm{O}=60 \mathrm{mg} / \mathrm{l}, 100 \mathrm{mg} / \mathrm{l}$ for Photo-Fenton, Fenton and $\mathrm{UV} / \mathrm{H}_{2} \mathrm{O}_{2}$ system, respectively

By these figures it can be observed that the removal efficiency decreases linearly in Photo-Fenton from $79.4 \%$ to $28.05 \%$ as the concentration of oil increases from 1000 to $3000 \mathrm{mg} / \mathrm{l}$ respectively. Similarly, in $\mathrm{UV} / \mathrm{H}_{2} \mathrm{O}_{2}$ process the maximum removal efficiency at $1000 \mathrm{mg} / 1$ was $21.31 \%$ and decrease down to $(18.17) \%$ at 3000 $\mathrm{mg} / \mathrm{l}$. In Fenton process the removal efficiency increased at the oil concentration increased up to $2000 \mathrm{mg} / \mathrm{l}$, from $(53.22 \%)$ to $(24.62 \%)$.

This can be attributed to the increase in COD which leads to high turbidity of the solution. In Photo-Fenton the COD for $3000 \mathrm{mg} / \mathrm{L}$ oil solution was measured to be 5861 , whereas for $1000 \mathrm{mg} / \mathrm{L}$ oil solution the COD was 2587 only. As turbidity in the solutions during the photo treatment hinders the absorption of the UV light for the 
photo Fenton process (Rodriguez et al., 2002). (Dincer et al., 2008) diluted wastewater with 21000 ppm COD ( $80 \%$ )in order to treat it with Photo-Fenton. On the other, more COD was removed at higher oil conc. (COD strength) than lower COD in Fenton process and this may due to the absence of UV irradiation and turbidity effect, also because it enhances the attack on the organic matter due to its high content.

\subsection{The Effect of Temperature}

Reaction temperature is another important process parameter that affects the degradation process. Different temperatures $(20,30 \text { and } 40)^{\circ} \mathrm{C}$ were used. The dosage of the reagents and other parameters were remained constant as obtained from previous sections.

The results were plotted in Figure (6). These figures shows that the COD removal efficiency increases at $30^{\circ} \mathrm{C}$ and then decreased at $40^{\circ} \mathrm{C}$ for Photo-Fenton process. For Photo-Fenton and $\mathrm{UV} / \mathrm{H} 2 \mathrm{O} 2$ system the maximum removal efficiency were 80.59 and $22.69 \%$, respectively. For Fenton process the removal efficiency is $53.22 \%$ at $20^{\circ} \mathrm{C}$

The increase in temperature accelerated the decomposition of $\mathrm{H}_{2} \mathrm{O}_{2}$ thus increasing the generation of $\mathrm{OH}$ radicals which enhances the degradation process slightly. There is no significant COD removal different with different temperatures; the range of the COD removal on predetermined time for these three different temperatures is less than $10 \%$. This finding is in agreement with the previous observation of (Leong \& Bashah, 2012). The optimal temperature is in the range of $20-40^{\circ} \mathrm{C}$ and this result is similar to other researches findings (Leong \& Bashah, 2012; Lucas \& Peres, 2009; Nieto et al., 2011).

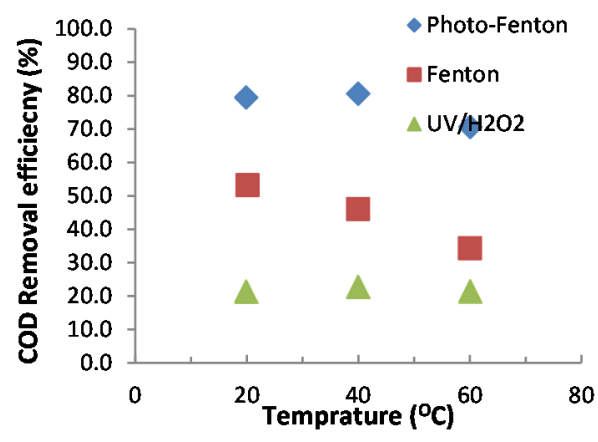

Figure 7. Effect of temperature on the COD removal at $\mathrm{pH}=3$, oil concentration $=1000 \mathrm{mg} / \mathrm{l}, 2000 \mathrm{mg} / \mathrm{l}, 1000$ $\mathrm{mg} / 1, \mathrm{H}_{2} \mathrm{O}_{2}=800 \mathrm{mg} / \mathrm{l}, 1500 \mathrm{mg} / \mathrm{l}, 2000$ and $\mathrm{Fe}_{2} \mathrm{SO}_{4} \cdot 7 \mathrm{H}_{2} \mathrm{O}=60 \mathrm{mg} / \mathrm{l}, 100 \mathrm{mg} / \mathrm{l}$ for Photo-Fenton, Fenton and $\mathrm{UV} / \mathrm{H}_{2} \mathrm{O}_{2}$ system, respectively

\section{Conclusions}

The COD removal from synthetic vegetable oil wastewater was investigated by the Photo-Fenton, Fenton and $\mathrm{UV} / \mathrm{H}_{2} \mathrm{O}_{2}$ processes. The COD removal efficiency was strongly affected by many factors such as the concentration of $\mathrm{H}_{2} \mathrm{O}_{2}, \mathrm{Fe}_{2} \mathrm{SO}_{4} .7 \mathrm{H}_{2} \mathrm{O}, \mathrm{pH}$, temperature and the oily content amount.

It was found that the Photo-Fenton, Fenton and combination of $\mathrm{UV}$ and $\mathrm{H}_{2} \mathrm{O}_{2}$ processes have the potential to partially reduce the COD of oily wastewater in different removal percentage. The overall results of this study indicate that the application of Photo-Fenton process is a feasible method to treat vegetable oily content wastewaters achieving a significant decrease of COD. Optimum initial $\mathrm{pH}$ was found 3 for all three processes studied, temperature of $30^{\circ} \mathrm{C}$ was found optimum for Photo-Fenton and $\mathrm{UV} / \mathrm{H}_{2} \mathrm{O}_{2}$ system and $20^{\circ} \mathrm{C}$ for Fenton system. Optimum chemical reagents dosage for Photo-Fenton at $\mathrm{H}_{2} \mathrm{O}_{2}=800 \mathrm{mg} / \mathrm{l}$ and $\mathrm{Fe}_{2} \mathrm{SO}_{4} .7 \mathrm{H}_{2} \mathrm{O}=60 \mathrm{mg} / \mathrm{l}$, leads to a COD reduction of $80.59 \%$. Fenton's reagent at $\mathrm{H}_{2} \mathrm{O}_{2}=1000 \mathrm{mg} / \mathrm{l}$ and $\mathrm{Fe}_{2} \mathrm{SO}_{4} .7 \mathrm{H}_{2} \mathrm{O}=1500 \mathrm{mg} / \mathrm{l}$, leads to a $\mathrm{COD}$ reduction of $53.22 \%$. UV/ $\mathrm{H}_{2} \mathrm{O}_{2}$ combination process a low COD removal efficiency $22.69 \%$ was found.

\section{References}

Alade A. O., Jameel A. T., Muyubi A. S., Abdul Karim M. I., \& Alam, M. D. Z. (2011). Removal of oil and grease as emerging pollutants of concern (EPC) in wastewater stream. Iranian Journal of Oil \& Gas Science and Technology, 2(4), 01-11

Alalm M. G., \& Tawfik, A. (2013). Fenton and solar Photo-Fenton oxidation of industrial wastewater containing pesticides. Seventeenth International Water Technology Conference, IWTC17. 
Chatzisymeon E., Stypas, E., Boosios, S., Xekoukoulotakis, N. P., \& Mantzavinos, D. (2008). Photocatalytic treatment of black table olive processing wastewater. J. Haz. Mater., 154, 1090-1097.

Chin, K. K., \& Wong, K. K. (1981). Palm oil refinery wastes treatment. Water Res., 15, 1087.

De Laat, J., \& Gallard, H. (1999). Catalytic decomposition of hydrogen peroxide by Fe(III) in homogeneous aqueous solution: Mechanism and kinetic modeling. Environmental Science and Technology, 33, 2726-2732.

Dincer, A. R., Karakaya, N., Gunes, E., \& Gunes, Y. (2008). Removal of COD from Oil Recovery Industry wastewater by the Advanced Oxidation Processes (AOP) based on $\mathrm{H}_{2} \mathrm{O}_{2}$. Global NEST Journal, 10(1), 31-38.

Ebrahim, M., Mustafa, Y. A., \& Alwared, A. I. (2013). Removal of oil wastewater by advanced oxidation process/homogenous process. Journal of Engineering, 6(19).

Esplugas, S., Gimenez, J., Contreras, S., Pascual, E., \& Rodriguez, M. (2002). Comparison of different advanced oxidation processes for phenol degradation. Water Res., 36(4), 1034-42.

Fadzil, N. A. M., Zainal, Z., \& Abdullah, A. H. (2013). COD Removal for Palm Oil Mill Secondary Effluent by Using UV/Ferrioxalate/ $/ \mathrm{TiO}_{2} / \mathrm{O}_{3}$ system. International Journal of Emerging Technology and Advanced Engineering, 3(7), 237-243.

Galvão S. A. O., Mota, A. L. N., Silva, D. N., Moraes, J. E. F., Nascimento, C. A. O., \& Chiavone-Filho, O. (2006). Application of the photo-Fenton process to the treatment of wastewaters contaminated with diesel. Science of The Total Environment, 367, 1(15), 42-49.

Gunstone, F. (2005). Bailey's Industrial Oil and Fat Products (6th Ed.). Vegetable oils, 1, 213 - 269. Wiley Interscience, Memorial University of Newfoundland, Canada.

Leong, S. K., \& Bashah, N. A. A. (2012). Kinetic study on COD removal of palm oil refinery effluent by UV-Fenton. APCBEE Procedia, 3, 6-10.

Li, R., Yang, C., Chen, H., Zeng, G., Yu, G., \& Guo, J. (2009). Removal of triazophos pesticide from wastewater with Fenton reagent. Journal of hazardous materials, 167(1), 1028-1032.

Lucas, M. S., \& Peres, J. A. (2009). Removal of COD from olive mill wastewater by Fenton's reagent: Kinetic study. J Hazard Mater, 168(2-3), 1253-1259.

Mota, A. L. N., Albuquerque, L. F., Beltrame, L. T. C., Chiavone-Filho, O., Machulek, Jr. A., \& Nascimento, C. A. O. (2008). Advanced oxidation processes and their application in the petroleum industry a review. Brazilian Journal of Petroleum and Gas, 2(3), 122-142.

Nasr, B., Ahmed, B., \& Abdellatif, G. (2004). Fenton treatment of olive oil mill wastewater-applicability of the method and parameters effects on the degradation process. Journal of Environmental Sciences, 16(6), 942-944.

Ng, W. J. (2006). Industrial Wastewater Treatment. London: Imperial College Press.

Nieto, L. M., Hodaifa, G., Rodraguez, S., Gimacnez, J. A., \& Ochando, J. (2011). Degradation of organic matter in olive-oil mill wastewater through homogeneous Fenton-like reaction. Chem Eng J, 173(2), 503-510.

Rodriguez, M., Sarria, V., Esplugas, S., \& Pulgarin, C. (2002). Photo-Fenton treatment of a biorecalcitrant wastewater generated in textile activities: biodegradability of the phototreated solution. J Photoch Photobio A, 151, 129-135.

Sharma, S., Ashok, K. Sharma, Sanjay, V., Himmat, S. D. (2014). Edible oil refinery waste water treatment by using effluent treatment plant. International Journal of Chemical Studies, 2(3), 36-42.

Wols, B. A., \& Hofman-Cari, C. H. M. (2012). Review of photochemical reaction constants of organic micropollutants required for UV advanced oxidation processes in water. Water Research, 46(9), 2815-2827.

\section{Copyrights}

Copyright for this article is retained by the author(s), with first publication rights granted to the journal.

This is an open-access article distributed under the terms and conditions of the Creative Commons Attribution license (http://creativecommons.org/licenses/by/3.0/). 